\title{
Why were Casualties so low?
}

Steve Fetter, George N. Lewis, and Lisbeth Gronlund

Nature, Vol. 361 (28 January 1993), pp. 293-296.

\section{Patriot missiles were returned to the Gulf last week. But they were not the reason for the unexpectedly low casualty rate when Saddam attacked Israel with Scud missiles in 1991.}

IRAQ fired more than 80 modified Scud missiles at Israel and Saudi Arabia during the 1991 Persian Gulf War. These attacks caused 31 deaths, numerous injuries, and substantial property damage. With the exception of the Scud that hit a barracks in Dhahran, Saudi Arabia, and killed 28 U.S. soldiers, however, the number of deaths and serious injuries caused by each Scud appear to be much lower than one would have expected based on the results of previous ballistic missile attacks. The relatively low casualty rate has been cited by several analysts as evidence of the success of the Patriot missile defense system. ${ }^{1-5}$ Others have argued that the same casualty data suggests that the Patriot may not have been very successful. ${ }^{6}$

What effect did Patriot have on casualties during the Gulf War? Here we show that the publicly available data do not support claims that Patriot played a significant role in preventing casualties or damage to buildings in Israel. (We focus on Israel because relatively little data are available from Saudi Arabia.) Why, then, were casualties so low in Israel? To answer this question, we review the effects of previous ballistic-missile attacks on cities and discuss various factors that may account for the lower casualty rate in Israel.

\section{Role of Patriot}

The Scud attacks on Israel began on the morning of 18 January 1991, but the first Patriot battery did not become operational until after 11 Scuds had fallen. Of the 38 Scuds that reached Israel, 27 were fired after Patriot was operational; of these, 17 were engaged by Patriot missiles. ${ }^{7}$ Most or all of the other ten Iraqi missiles fell in areas not covered by the Patriot batteries deployed near Tel Aviv and Haifa.

According to the US Army's most recently revised estimates of Patriot effectiveness, of the 17 engagements in Israel, only 40\% were successful, and the Army stated that it had "high confidence" in only $40 \%$ of its claimed successful engagements in Israel and Saudi Arabia. ${ }^{8}$ Thus, of the seventeen Scuds engaged, at most seven were intercepted, and in only three of these cases does the Army claim high confidence (assuming equal confidence levels in Israel and Saudi Arabia). The Army claims have been challenged by independent analysts. ${ }^{9,10}$ But even if we accept the Army's data, Patriot would have reduced the expected casualty rate by no more than 16 to $40 \%$. Moreover, any damage prevented by successful intercepts must be weighed against 
the damage caused by the four Patriot missiles that struck the ground and exploded in Israel, ${ }^{2,11}$ as well as by the debris from intercepted Scuds and from Patriots that detonated above cities. Because of the lack of accurate track data on the Scud and Patriot missiles, the effect of Patriot in mitigating casualties and damage in Israel will never be known with any certainty. Given that large statistical fluctuations would be expected in the damage from small numbers of inaccurate ballistic missiles armed with conventional warheads, any effect that Patriot may have had on casualties or damage is lost in the noise.

Casualty and damage statistics before and after Patriot deployment support this conclusion. The 38 modified Scud missiles fired at Israel directly killed two people and injured about 230 more. Almost all the injuries were light, with only ten classified as moderate and one as severe. $^{12,13}$ Of the direct casualties, 52 occurred before Patriot was operational (4.7 per missile) and 179 after (6.6 per missile). ${ }^{12}$ All but two of the 179 casualties after Patriot was operational were caused by Scuds that fell in defended areas. Both deaths and most or all of the serious injuries occurred during the period of Patriot defense.

The situation with respect to property damage is more complicated. Theodore Postol has published a translation of a compilation of damage to buildings that appeared in the Tel Aviv newspaper Ma'ariv. ${ }^{6}$ According to Ma'ariv, 2,797 apartments suffered damage before Patriot (254 per missile) and 9,029 after Patriot was operational (334 per missile). Much of the damage to apartments was very light (such as broken windows). If only apartments that were seriously damaged or destroyed are counted, the figures are 40 per missile before Patriot and 34 after Patriot.

Thus, although serious damage to apartments appears to have decreased slightly after Patriot became operational, light damage, injuries, and deaths all increased. Given the small number of Scud impacts in inhabited areas, however, these differences are not statistically significant. One can only conclude that the available data do not support the hypothesis that Patriot had a significant effect on casualties or damage.

\section{Previous ballistic attacks}

A review of the effects of previous ballistic-missile attacks helps to put the Israeli casualty rate in perspective. Before the 1991 Gulf War, ballistic missiles were used extensively in war only three times: the Germans launched over 3,000 V-2 missiles against urban British and European targets during World War II; Iraq and Iran together launched nearly 1,000 missiles against each other's cities during the 1980-88 Persian Gulf War; and the Kabul government fired over 2,000 Sovietmade Scud missiles against Mujahideen guerrillas in the Afghanistan civil war. In all cases the missiles were armed with conventional high-explosive warheads. Detailed information on casualties and physical damage is, however, available only for the V-2 attacks on London.

V-2 attacks on London. From September 1944 until March 1945, Germany launched over 3,000 V-2 ballistic missiles at targets in Britain and continental Europe. Of the approximately 1,400 V-2s fired against Britain, 518 fell in the London Civil Defense District. In addition, nearly $10,000 \mathrm{~V}-1$ cruise missiles were fired against London. Even though most of the V-1s malfunctioned or were destroyed by British defenses, about 2,420 fell in London. 
Although the V-2 and the V-1 warheads had nearly equal explosive yields and created roughly equal amounts of property damage per missile, ${ }^{14}$ each V-2 impact in London resulted in an average of 4.8 deaths and 11.7 serious injuries, compared to 2.2 deaths and 6.3 serious injuries per V-1 impact. ${ }^{15}$ The lower casualty rate for the V-1 was due primarily to the fact that people in the target area could hear the V-1 approach and could take cover before its warhead exploded, while the V-2 gave no warning of its approach. ${ }^{16}$

Scud attacks on Teheran. Only limited information is available on casualties and damage from the Iraqi Scud attacks on Teheran during the so-called "War of the Cities." A total of 189 modified Scud missiles fell on six different Iranian cities from 29 February to 20 April 1988; 135 of these landed in Teheran. ${ }^{17}$ On 4 April, after about 125 missiles had fallen, Iranian sources reported that 1,150 people had died and 4,000 had been injured from the missile attacks; some foreign analysts believe that Iran under-reported casualties to minimize civilian panic, and estimate that 2,000 people died. ${ }^{18}$ Thus, about 10 to 15 people were killed and at least 30 injured per missile impact.

If we assume that the circumstances of the Scud attacks on Teheran were similar to those of the V-2 attacks on London, we need only modify the London casualty estimates to account for differences in population density and warhead yield to estimate the expected casualty rate in Teheran. The population densities of Teheran and London before the Scud and V-2 attacks were about 300 and 43 per hectare, respectively; the available information suggests that roughly 20 percent of the population was evacuated during the attacks in both cases. ${ }^{14}$ All else being equal, a given warhead would on average kill and injure about seven times as many people if targeted against Teheran rather than London under the circumstances described here.

The modified Scud reportedly carried a warhead with 160 to 190 kilograms of high explosive $;^{17}$ including the kinetic energy of the missile, which was reduced by its tendency to break up during reentry, the total energy released on impact would have been equivalent to no more than 250 kilograms of TNT, compared to 900 kilograms of TNT for the V-2. ${ }^{14}$ Since the area subjected to blast damage scales as the yield to the two-thirds power, the lethal area created by the impact of the modified Scud was 0.43 times that of the V-2.

Thus, scaling for differences in population density and warhead yield, the expected casualty rate in Teheran is three times greater than that in London, or 14 deaths and 35 serious injuries per Scud impact. This estimate is in good agreement with the available (albeit sparse and unreliable) information about casualties in Iran cited above. We should stress, however, that a detailed comparison with the London experience has not been done because we lack information about many important aspects of the attacks on Teheran (civil defense, construction practices, and so on). As we shall see in the case of the attacks on Israel, such factors can have a significant effect on casualties.

\section{Scud attacks on Israel}

As noted above, the 38 modified Scud missiles fired at Israel resulted in 2 direct deaths, 11 serious injuries, and about 220 minor injuries. The number of Israeli casualties produced by the modified Scud missiles seems remarkably low compared with previous ballistic missile attacks. In 
fact, the total number of deaths and serious injuries in Israel was less than that caused by just one average missile impact in London or Teheran.

As discussed above, it is necessary to account for differences in population density and warhead yield when estimating casualties. Most of the casualties occurred in the Tel Aviv metropolitan area, which had a population density of about 70 per hectare in $1991 .{ }^{14}$ As was the case in London and Teheran, many people left Tel Aviv during the missile attacks. Although this evacuation was widely noted in the press, its extent is difficult to estimate, especially since many of the evacuees left only at night, returning to their jobs in the morning. In the absence of better information, we assume the same fraction of evacuees as in London, which gives a nighttime population density about 1.6 times that of London during the missile attacks.

The modified Scud missile used against Israel was apparently the same as that used against Iran, and it appears that essentially all of the missiles launched by Iraq during the Gulf War also broke up on reentry. After applying the appropriate scaling factors for population density and warhead yield to the casualty rates from V-2 attacks on London, one would expect about 3.3 deaths and 8.1 serious injuries per Scud impact in Tel Aviv. Thus, the actual number of deaths that resulted from the 38 missiles launched against Israel was more than 60 times less than what one might have expected based on this straightforward extrapolation from the experience in London. This simple analysis, however, omits several important factors.

Warning time. A major difference between the missile attacks on London and Teheran and those on Tel Aviv was that (except in the first two attacks) the Israeli population generally had a few minutes warning time in which to take cover. This was because the U.S. shared satellite information on Scud launches with Israel. We can account for this very approximately by comparing the casualty rate for the V-1 attacks, for which there was some warning, with that for the V-2 attacks, for which there was no warning. After correcting for its slightly smaller yield, the death rate from $\mathrm{V}-1$ attacks was 0.5 times that from the $\mathrm{V}-2$ attacks ( 0.58 for serious injuries). Thus, taking into account warning time in addition to population density and warhead yield, the expected rates are reduced to 1.6 deaths and 4.7 serious injuries per missile impact in Tel Aviv.

Another factor that may have reduced casualties is that virtually all of the missile attacks on Tel Aviv occurred at night, whereas the attacks on London occurred throughout the day. Thus, most Israelis were at home during the attacks, and on hearing the warnings simply had to go into interior rooms to obtain a degree of shelter.

Inaccuracy of the modified Scud. A key factor in limiting the damage to Israel was that most of the modified Scud missiles did not strike populated areas. According to a study of Israeli casualties, only six warhead explosions caused direct casualties. ${ }^{13}$

The basic Scud-B is so inaccurate that, at its maximum range of $300 \mathrm{~km}$, at least half of the impacts would fall more than $1 \mathrm{~km}$ from the target. ${ }^{19}$ Moreover, the pressure the Iraqis were under to launch the missiles quickly, combined with the modifications made to the missile by Iraq to more than double its range, undoubtedly led to a substantial decrease in the accuracy of the missile. 
It is difficult to determine the number of Scud impacts in Israeli cities because Israeli censorship regulations did not allow the release of the precise locations of Scud impacts. In the 15 attacks involving a single Scud missile, however, there is little difficulty in identifying the cases in which a warhead detonated in a populated area: three such warheads exploded in populated areas in or near Tel Aviv; the other twelve warheads presumably fell in uninhabited areas, were duds or were destroyed by Patriot missiles.

It is more difficult to sort out what occurred in the four multiple-Scud attacks in which a total of 23 missiles were launched at Tel Aviv and Haifa. The first two attacks occurred before Patriot was operational. Seven missiles were fired at Tel Aviv and Haifa at about 2 a.m. on 18 January 1991, and four missiles were fired at Tel Aviv at about 7 a.m. on the following day. Robert Stein, manager of Advanced Air Defense Programs for Raytheon (Patriot's manufacturer), states ${ }^{1}$ that the majority of these missiles "were not on target, and only very few fell on Tel Aviv." Taken literally, this means that no more than five Scuds were on target; as discussed below, at least one of these did not explode. A Pentagon briefing on 25 January 1991 also implied that no more than five of these missiles landed in populated areas and caused damage. ${ }^{14}$

The other two multi-Scud attacks occurred during the period of Patriot defense: seven missiles were launched on 25 January and five the next day. In the first attack, only two clearly identifiable explosion sites in populated areas were reported: one in a residential neighborhood and one at a school. The only impact reported in a populated area in the second attack occurred on a deserted beach in Tel Aviv.

Thus, it appears that only about 10 Scud warheads exploded in populated areas in Israel. What happened to the other 28? Some landed well short of Tel Aviv or in the Mediterranean Sea. It is possible that others landed in unpopulated areas in or near Tel Aviv and Haifa but went unreported by the news media. An anonymous senior Pentagon scientist was reported ${ }^{7}$ as saying that Scuds not engaged by Patriot "either fell in the sea or out of range of the Patriot batteries, near towns in the West Bank or in the Negev desert." One study noted ${ }^{13}$ that of the missiles launched against Israel, "a number fell in the sea or exploded in the air." Finally, some Scuds may have been destroyed by Patriots, and, as noted below, at least one of the warheads that landed in Tel Aviv was a dud.

Blast-resistant dwellings. One Israeli study of the Scud casualties concluded that the most important factor in reducing casualties was the construction practices used in modern Israeli apartment buildings. ${ }^{13}$ The multi-story apartment buildings erected in Tel Aviv over the last 30 years are constructed with reinforced concrete columns, beams, and floors. ${ }^{13,20}$ The reinforced concrete elements prevented buildings close to Scud detonations from collapsing and burying their inhabitants. On the other hand, when missiles struck near older, unreinforced masonry buildings, these were often completely demolished, with the roof and walls collapsing.

By contrast, the typical London dwelling was the brick-row house, which often collapsed from the blast of nearby V-2 explosions. The limited data available on the effects of V-2 missiles on reinforced concrete buildings in London indicates that the area of structural damage is roughly eight times smaller than for brick-row houses. ${ }^{16}$ Because deaths and serious injuries are due 
primarily to the structural collapse of buildings, Israeli construction practices were probably a significant factor in reducing the casualty rate relative to that in London.

Dud warheads. Some Scud warheads simply failed to detonate. In the second attack on Israel, a warhead penetrated several floors of a building before coming to rest in a ground-floor jewelry store, where it was recovered intact. ${ }^{21}$ There were also reports that one or more of the missiles fired at Israel did not carry explosive warheads. ${ }^{22}$ Given the ample evidence that many of the warheads that landed in populated areas did explode, however, the fraction of duds was probably small.

Civil defense. Most of the beneficial effect of civil defenses has already been accounted for in the discussion of warning time and construction techniques. Israel devoted substantial resources to rapid rescue efforts, and several people were reportedly rescued from collapsed buildings. But it is unlikely that Israeli efforts were much better than those of the British rescue services, which had experienced several years of German air attacks. Thus, civil defense probably played a minor role in reducing the casualty rate relative to that in London.

Coincidence. Substantial statistical fluctuations are expected in attacks involving only a small number of inaccurate ballistic missiles with small damage radii. Since only about ten warheads detonated in Israeli cities, luck must have played a crucial role in determining the overall casualty rate. Indeed, there is considerable anecdotal evidence that good fortune played an important role in reducing casualties in Israel. Of the warheads that detonated in Israeli cities, one hit the only empty lot in a densely populated neighborhood; ${ }^{23}$ two others hit a factory and a partially constructed shopping mall during the night. Several other Scuds landed near unoccupied buildings: an underground bomb shelter, a municipal center, and a school. Even when Scuds severely damaged occupied buildings, casualties were remarkably low: a missile that landed in an alleyway between several apartment buildings and caused one building to collapse killed only one person, and an attack that destroyed a two-storey house and severely damaged several others also killed only one person; two people reportedly survived only because they disobeyed government instructions and went to their basement bomb shelter.

\section{Conclusions}

Given the number of missiles fired, casualties in Israel at first appear to be very low compared to what could be expected based on previous ballistic missile attacks. However, several characteristics of the modified Scud helped to limit casualties, most notably the inaccuracy of the missile (only about one-quarter of the missiles detonated in populated areas in Israel), together with its small warhead, its break-up on reentry and an unknown but probably small number of dud warheads.

Several other factors also appear to have played an important role in reducing casualties. The difference in the V-1 and V-2 casualty rates suggests that the warning time provided by US launch-detection satellites reduced casualties by a factor of two. In addition, coalition air attacks forced Iraq to launch missiles after dark, when most Israelis were at home. 
Taken together, the above factors allow us to estimate, based on the London V-2 experience, that 16 deaths and 47 serious injuries would have been expected from the roughly 10 Scud detonations in Israeli cities, excluding casualties that may have been caused by the 4 Patriot impacts. Two deaths and eleven serious injuries actually occurred. Much of this apparent discrepancy may be due to Israeli construction practices, which prevented the collapse of heavily damaged buildings. As noted above, the limited data from London indicates that the area of destruction for reinforced concrete buildings was about eight times smaller than that for brick-row houses.

Given the significant statistical fluctuations that would be expected in a casualty rate based on such a small number of explosions, the factors discussed above can account for the observed casualty rate in Israel. However, anecdotal also suggests that luck helped to reduce casualties. As illustrated by the Scud that hit the barracks in Dhahran and killed 28 soldiers, shifting the impact point of a single missile by tens of metres could have changed the casualty statistics dramatically, given the small number of warheads that detonated in Israeli cities.

The available evidence does not support claims that the Patriot missile defense system significantly reduced casualties in Israel. While Patriot might have destroyed some warheads that would otherwise have caused casualties, the available data contain no evidence for a net reduction in casualties or damage due to Patriot.

Several important lessons can be drawn from the experience of the Gulf War. The widely held belief that ballistic missiles are themselves weapons of mass destruction is simply incorrect, as demonstrated by this as well as past episodes. It is the nature of the warhead, not the mode of delivery, that counts. However, even attacks with conventional warheads could be far more lethal. If a few missiles had struck crowded buildings, or if the missiles had been more accurate or had carried larger warheads, or if the attacks had taken place during the day rather than during the night, the number of deaths could have been many times greater. Finally, warning of missile attack, which in this case was made possible by satellites, can save lives by allowing people to shelter or take other evasive action.

Steve Fetter is in the School of Public Affairs, University of Maryland, College Park, MD 20742, USA. George N. Lewis is in the Defense and Arms Control Studies (DACS) Program, Massachusetts Institute of Technology, Cambridge, MA 02139, USA. Lisbeth Gronlund is at the Union of Concerned Scientists, 26 Church Street, Cambridge, MA 02138, USA, and is a research fellow at DACS. This article is based on a more detailed paper (ref. 14.)

1. Robert Stein, "Correspondence: Patriot Experience in the Gulf War," International Security, Vol. 17, No. 1 (Summer 1992), p. 200.

2. Charles Zraket, "Patriot Gave Stellar Gulf Performance," Defense News, 9 December 1991, p. 31.

3. Robert L. Pfaltzgraff Jr., "An Unjustly Criticized Patriot," Wall Street Journal, 8 April 1992, p. A20.

4. "Conyers vs. the Patriots," Detroit News, 13 April 1992, p. 8. 
5. Max Boot, "New US House Committee Report Will Say Patriot Missile Failed," Christian Science Monitor, 23 September 1992, p. 9.

6. Theodore A. Postol, "Lessons of the Gulf War Patriot Experience," International Security, Vol. 16, No. 3 (Winter 1991/92), pp. 119-171.

7. Eric Schmidt, "Israel Plays Down Effectiveness of Patriot Missile," New York Times (International edition), 31 October 1991, p. A8.

8. Eric Schmidt, "Army Cuts Back Its Estimate on Patriot Missile's Scud Toll," New York Times, 8 April 1992, p. A11.

9. U.S. General Accounting Office, Operation Desert Storm: Data Does Not Exist to Conclusively Say How Well Patriot Performed, GAO/NSIAD-92-340, September 1992.

10. George N. Lewis and Theodore A. Postol, An Evaluation of the Army Report "Analysis of Video Tapes to Assess Patriot Effectiveness," Dated 31 March 1992: A Study Performed in Response to a Request by Congressman John Conyers, Jr., Chairman of the House Government Operations Committee (Cambridge, MA: Massachusetts Institute of Technology, Defense and Arms Control Studies Program, September 1992).

11. Fred Kaplan, "Specialists Debate the Value of Patriot," Boston Globe, 5 May 1991, p. 1.

12. Avi Bleich, Anat Dycian, Meni Koslowsky, Zahava Solomon, and Michael Wiener, "Psychiatric Implications of Missile Attacks on a Civilian Population: Israeli Lessons from the Persian Gulf War," Journal of the American Medical Association, Vol. 268, No. 5 (5 August 1992), p. 613-615.

13. Eric Karsenty, Joshua Shemer, Itzhik Alshech, Bruno Cojocaru, Marian Moscovitz, Yair Shapiro, Yehuda L. Danon, "Medical Aspects of the Iraqi Missile Attacks on Israel," Israel Journal of Medical Sciences, Vol. 27 (November-December, 1991), pp. 603-607.

14. George N. Lewis, Steve Fetter, and Lisbeth Gronlund, "Casualties and Damage from Scud Attacks in the 1991 Gulf War," (Cambridge, MA: Massachusetts Institute of Technology, Defense and Arms Control Studies, January 1993).

15. C.L. Dunn, The Emergency Medical Services, vol. 1: England and Wales (London: Her Majesty's Stationery Office, 1952), p. 174, 179.

16. U.S. Strategic Bombing Survey, Physical Damage Division, "V-Weapons in London," Report No. 152, January 1947.

17. W. Seth Carus and Joseph S. Bermudez, Jr., "Iraq's Al-Husayn Missile Programme," Jane's Soviet Intelligence Review, Vol. 2, No. 6 (June 1990), pp. 242-248.

18. John Bierman, "A Battered City Under Siege," Maclean's, 18 April 1988, pp. 34-36.

19. Steven Zaloga, "Ballistic Missiles in the Third World: Scud and Beyond," International Defense Review, Vol. 11 (1988), p. 1427.

20. David Rudge, "Keeping Those Buildings Up," Jerusalem Post, 22 February 1991, p. 8.

21. Joel Brinkley, "Israel Says It Must Strike at Iraqis but Indicates Willingness to Wait," New York Times, 20 January 1991, p. 1.

22. "Iraq Fired Scud with Concrete Warhead," Flight International, 13-19 March 1991, p. 13.

23. Sabra Chartrand, "A Day of False Alarms and Fear, Flanked by Real Explosions," New York Times, 19 January 1991, p. A7. 